\title{
The Effectiveness of the Hybrid Learning Materials with the Application of Problem Based Learning Model (Hybryd-PBL) to Improve Learning Outcomes during the COVID-19 Pandemic
}

\author{
Thamrin $^{1 *}$, Saidun Hutasuhut ${ }^{1}$, Reza Aditia ${ }^{1}$, Fauziyah Riyan Putri ${ }^{2}$ \\ 1Universitas Negeri Medan, Medan, Indonesia \\ 2Universitas Negeri Yogyakarta, Yogyakarta, Indonesia
}

\begin{tabular}{|c|c|}
\hline  & DOI : $\underline{\text { https://doi.org/10.46245/ijorer.v3i1.178 }}$ \\
\hline Sections Info & ABSTRACT \\
\hline Article & Study aimed to see the effectiveness of the hybrid learning ma \\
\hline 17,2021 & application with Problem based learning (PBL) model to improve students' \\
\hline Final Revi & outcome in evaluation course in learning outcomes at the Business Education \\
\hline anuary & Study Program, State University of Medan. The study used a quasi- \\
\hline Publi & experimental method of the Posttest control group design. Data collection was \\
\hline Key & carried out by conducting tests after class. The sample selected in this study \\
\hline $\mathrm{COI}$ & were all students of the Business Education study program in evaluation \\
\hline Hyb & course in learning outcomes. The results showed that the application of \\
\hline tcome & hybrid learning with the PBL model was effective to improve learning \\
\hline & outcomes in evaluation course in learning outcomes. The results of this study \\
\hline Pro & also found that the independence and creativity of student learning was \\
\hline 口; & $\begin{array}{l}\text { higher by applying hybrid learning with problem-based learning models } \\
\text { compared to the control class. The results of this study contributed to the } \\
\text { lecturers' evaluation of learning outcomes in improving the quality of } \\
\text { learning, which has been traditional, by applying hybrid learning teaching } \\
\text { materials with problem-based learning models, especially during the current } \\
\text { Covid } 19 \text { pandemic and to answer the demands of learning in the industrial } \\
\text { revolution era. } 4.0 \text {. }\end{array}$ \\
\hline
\end{tabular}

\section{INTRODUCTION}

Each lecturer expects that the learning activities they carry out can achieve the goals set effectively, efficiently, attractively, and pleasantly so that the active learning process can be carried out to obtain maximum learning outcomes. To realize this expectation, lecturers must develop learning designs according to experience, knowledge, skills, and all available resources to support the optimal achievement of every learning activity. However, at this time, achieving this condition is not easy. Since 2020, the whole world has been shocked by the outbreak of the COVID-19 pandemic. This deadly virus has shaken all aspects of people's lives around the world, including education. With no vaccine yet found that can completely prevent humans from contracting COVID-19, one of the most reasonable ways is to limit social activities that involve physical contact, also known as Physical Distancing (Singh \& Adhikari, 2020). This situation has forced many schools and campuses to temporarily close face-to-face learning activities, which is undoubtedly a challenge for any educational institution. Every academic unit is struggling to find a solution to this problem. Educational institutions must not ignore every teaching staff and students' health, but on the other hand, must also ensure that every student achieves the targeted basic abilities.

One of the compulsory courses for students that they need to take is the Evaluation course of learning outcomes. This course is essential considering that this subject is a primary subject whose competencies must be mastered by students as prospective 
The Effectiveness of the Hybrid Learning Materials with the Application of Problem Based Learning Model (Hybryd-PBL) to Improve Learning Outcomes during the COVID-19 Pandemic

professional teachers in Economics and Marketing in Senior High Schools and Vocational High Schools in Indonesia. After they become teachers, they will be faced with the tasks of making test instrument to measure students competencies, which is one of the competencies as a professional teacher, namely pedagogic competence. To maximize learning in the Evaluation course of learning outcomes, the Business Education Study Program has provided its teaching materials. It is in the form of a textbook, but the learning instructions from this textbook have not fully met expectations when the learning process is carried out using hybrid learning. The impact of this problem is tremendous. The learning outcomes achieved by students are way farther from what is targeted. Especially during the current COVID-19 pandemic. This phenomenon can be seen from the data on student learning outcomes in the 2018/2019. Most students got a B grade (38 students), two students got a C grade, and only two students got an A grade.

The low student grades could be due to the online learning environment that is very different from traditional classrooms. When learning is carried out in traditional classrooms, generally, communication is carried out verbally, with visual cues and body language, whereas online communication occurs in virtual time in written text format with the addition of body language (Lin, 2008). From the satisfaction side, if online learning is compared with face-to-face or traditional instruction, students who enrolled in the online course were significantly less satisfied with the course than the traditional classroom (Bolliger, 2004; Hayashi et al., 2020; Martin \& Bolliger, 2018). Another phenomenon can be seen through discussions with a lecturer in the Guided Teaching Course (Apprenticeship 3) and researchers' experience in teaching courses of evaluation of learning outcomes. The lack of students' ability to follow the 21st-century learning demands is one of the weaknesses that need to overcomed. The ability to analyze the validity, reliability, differentiation power and difficulty level of the test is still relatively less than the maximum. The test designed has not reached the category of high-order thinking skills (HOTS). When referring to Bloom's Taxonomy (Bloom \& others, 1956) which was later refined by Anderson and Krathwohl (Anderson et al., 2001; Krathwohl, 2002), the constructed tests are still at the 'Remember' (C1), 'Understand' (C2), and 'Apply' (C3) levels.

This situation is in line with Wijaya \& Suyono (2019) research finding, which explains that the skills of Accounting Education Study Program students in developing questions with HOTS standards are still somewhat low compared to the ability to compose questions in the LOTS category. This condition is suspected because when students attending the lectures, the evaluation of learning outcomes do not have optimal competence. This phenomenon can be seen when the researcher guides the Apprenticeship 3 course, in which the Apprenticeship 3-course students compile a learning plan in which there is a test instrument. One of the weaknesses of the students participating in Apprenticeship 3 is their inability to design HOTS learning outcomes tests. This condition is suspected because when students attend lectures on the evaluation of learning outcomes, they do not have adequate competence.

Before carrying out the research, the authors conducted some interviews with several students. After the interview was completed, it was found that the main reason for the lack of optimal competence of students who attend this course, especially in compiling HOTS learning outcomes tests, is that because the condition of lecturer using unattractive teaching material. Not only that, the lack of competence of students is suspected because learning materials are not combined with information technology 
that students preferred today. Students want learning materials following the current state of learning, which uses technology and online learning way more than before. This is due to the student demographic in which they are all included as Generation Z. This generation has its uniqueness because they were born on well-established technology and use technology in almost every aspect of their daily lives. That is why they are even known as digital natives (Prensky, 2001).

This situation must be addressed, lest the students who will become teachers in the future but do not have adequate skills when teaching their fields of knowledge in class, whether high school or vocational high school. Efforts that can be made to overcome the problems are to develop teaching materials for the evaluation of learning outcomes in Hybrid learning courses with a problem-based learning model. Hybrid learning combines classroom learning with distance learning (online) to repeat the lessons they receive without being limited by space and time. With the current situation, using technology in the learning process will lead students to be able to achieve targeted learning outcomes. In addition, with the current pandemic situation, learning inevitably has to be held with hybrid learning. However, in the COVID-19 pandemic era, $100 \%$ of learning is carried out through networks that need learning materials that use information technology. This condition further encourages how this hybrid teaching material is needed. The use of Hybrid learning teaching materials with the PBL model has never been used at the Faculty of Economics Unimed in learning, not only in this course but in other courses at the Faculty of Economics, Unimed. Thus, this study's results can help improve the quality of learning following the learning perspective of the 21st Century and the era of the Industrial Revolution 4.0, especially during the COVID-19 pandemic. The findings of this study will help enrich the quality of learning in the Business Education Study Program in the long term, which in turn helps people form future students with a good character such as creative thinking, critical thinking, collaborative and communicative thinking through problem-based learning that is integrated with Hybrid learning teaching materials. In addition, this research is becoming increasingly relevant because, in Indonesia itself, there is a plan to transition from fully online learning, which has been carried out due to the COVID-19 pandemic, to hybrid learning. So that stakeholders can later use the findings of this research to determine policies that will be implemented on campuses.

\section{Literature Review}

Hybrid Learning

In the 21st century era, majority students are considered as Z-generation. In addition, they are also referred to as digital natives because they were born in a time when information technology was well established and they use the technology well (Prensky, 2001). They spend their entire life surrounded by and using computers, videogames, digital music players, video cameras, cell phones, and all the other toys and tools from the digital age. Today, the average college graduate spends less than 5,000 hours reading their lives, but more than 10,000 hours playing gem video (not to mention 20,000 hours watching TV) (Ceylan \& Kesici, 2017). It was also explained that video games, instant messaging, email, and cellphones are very much associated with their daily lives. On this basis, policymakers need to change learning patterns that follow the current situation if they want to be serious in educating this new generation.

That is why teaching materials must be following the development of the 21st century. Despite high recognition of it, pure online learning has some limitations 
(Olapiriyakul \& Scher, 2006). Furthermore, Rovai \& Jordan (2004) states that dependent learners are less-regulated and need frequent direction and reinforcement from a visible instructor, it makes they can be lost during the course easily. Following the research results by Hariadi et al. (2016), explaining that students who use hybrid applications, $79 \%$ feel comfortable in theirlearning process. As for lecturers, data were obtained from 70 lecturers, $82 \%$ of whom stated that the hybrid application helped their teaching process. This situation is in line with research results from Lin (2008). Results showed that a majority of students held positive views.

Teaching materials are a set of materials arranged that allow students to learn and are followed the current curriculum. Furthermore, it aims to achieve learning objectives. Some aspects that become the contents of teaching materials are ideas, facts, concepts, principles, rules, or theories about particular fields of science and other learning information. One of them is a module. Modules are self-study materials that are specially designed so that participants can learn at their own pace; anytime, anywhere, without the presence of an instructor/lecturer. Modules are usually presented in printed form. However, with the situation that requires learning to be carried out online, this module has been changed so that it can be accessed online.

Hybrid learning is known as a mixed mode ofinstruction, formally combining traditional face-to-face instruction and pure online learning (Olapiriyakul \& Scher, 2006). Research conducted by Tuapattinaya (2017) proves that learning can be more effective, efficient, and fun. This situation makes hybrid learning increasingly popular, especially at the higher education level ( $\mathrm{O}^{\prime}$ Shea et al., 2015). Moreover, learning through this hybrid teaching material has many advantages. Olapiriyakul \& Scher (2006) surveyed student perceptions of hybrid learning. As a result, students believed that hybrid learning was more fun and gave them a new, more enjoyable, and interactive experience. In addition, students also think that this type of learning should be more widely applied in the future. With the state of the COVID-19 pandemic that has not shown any decline at all, there is no best time to embrace hybrid learning. Some experts say there will come a time when 80 to 90 percent of total universities will use hybrid learning, increasing 30 percent annually (Horn \& Staker, 2011).

The hybrid module has the same content as the printed version, but because the module will be displayed online, this module must also be adapted to online media. The hybrid module elements consist of introduction, core parts, and closing section. This new module will be assembled into an e-learning application with a modified Moodle application in the Unimed Online Learning System (SIPDA). The strategy applied in learning is problem-based through worksheets designed to learn and acquire knowledge and skills through the problems posed to them. Furthermore, Tan (2021) states that the teacher-centered approach is considered traditional and needs to be changed to a student-centered learning strategy because learning which is centered on expository/direct lecturers is challenging to enable students to develop thinking skills, interpersonal skills, adaptability skills, even though these various skills are what they will need when they live their lives in the middle of society. One of the learning strategies can meet the learning process's demands is Problem Based Learning strategy.

\section{Problem Based Learning}

Problem-based learning (PBL) is learning that aims to improve high-level thinking skills in problem-oriented situations, including learning how to learn (Arends, 2012). Arends (2012) also states that the role of the teacher in this learning is very different from direct 
instruction; this is due to PBL, which is to explain problems, ask questions, and facilitate investigations and discussions that students will carry out. Furthermore, the teacher provides scaffolding that enhances their inquiry and intellectual growth. Furthermore, when referring to Carrió et al. (2011), when using PBL, the instructor will use a complex approach and real problems to stimulate analytical thinking and create appropriate questions to solve the problem. Thus, instructors who act as facilitators need to know the knowledge, concepts, and principles needed when carrying out the learning process (Cantillon et al., 2017; Cindy E. Hmelo-Silver1, 2004).

Various scholars who have contributed to the development of PBL (Calfee, 1996; Cognition \& at Vanderbilt, 1990; Krajcik \& Czerniak, 2007; Slavin et al., 1994) describe the characteristics of this learning, namely:

- Driving question or problem

- Interdisciplinary focus

- Authentic investigation

- Production of articats and exhibits

- Collaboration

Referring to Arends (2012), in general, there are 5 phases in the syntax when implementing PBL in providing learning, namely:

Phase 1: Orient students to the problem

Phase 2: Organize students for study

Phase 3: Assist independent and group investigation

Phase 4: Develop and present artifacts and exhibits

Phase 5: Analyze and evaluate the problem-solving process

Arends (2012) also emphasizes that when instructors carry out the learning process, they must also remember that the primary goal of learning when using PBL is not to deliver as much information or material as possible to students, but rather is how students are able to investigate the problems they face and become independent learners. In addition, there is no absolute truth or answer when students do the discussion, because often, as in the real world, complex problems require more than one solution, even contradictions to what is believed by the general public. Furthermore, when carrying out learning, students are invited to ask questions and seek relevant information on these questions. The role of the instructor is to provide assistance when needed so that students still have to try to find the answers themselves. Students are invited to communicate their ideas freely and openly when it comes to the analysis and explanation stage. There should be no ideas that are underestimated by students or other classmates.

When using PBL, students will work in small groups guided by the instructor to elaborate a hypothesis. That is why the role of the instructor is so crucial in PBL. Since the introduction of PBL, several studies that have systematically reviewed comparing PBL with traditional learning have been widely published. There has been some evidence that PBL is able to form students' critical thinking abilities (Tiwari et al., 2006), professional skills (Berkson, 1993), and can also foster interest and motivation to learn students (Michel et al., 2002; Vernon \& Blake, 1993). Furthermore, the findings of research conducted by Peters et al. (2000) found that students who carried out learning with PBL felt that they were helped in terms of developing humanistic, social skills, and thinking about professional issues. However, the existing literature does not entirely support PBL in student learning because there are also many inconsistent findings on 
the effectiveness of PBL compared to traditional learning (Hartling et al., 2010). Based on the findings of research conducted by (Schmidt et al., 1987), found that students who came from conventional learning programs tended to get better learning performance in terms of traditional academic achievement, although the difference was negligible. Berkson (1993) put forward an even louder rebuttal, who found that there was no evidence that PBL was able to enrich problem-solving skills, knowledge acquisition, or learning motivation in students who carried out learning using PBL. Furthermore, she also reported that PBL was costly and stressful, not only for students but also for faculty. Meanwhile, in 1993, (Vernon \& Blake, 1993) conducted a meta-analysis of 22 studies that found there is no differences in factual or clinical knowledge. However, what must be noted is that these objections come from studies that examine clinical students so that different things can happen if PBL is applied to courses in other fields of science

\section{RESEARCH METHOD \\ General Background}

During the research, Hybrid learning teaching materials have been applied with PBL student-centered learning model with the help of SIPDA Unimed e-learning. This study tries to determine the effect of the application of Hybrid learning teaching materials with the PBL model on the learning outcomes of Business Education Study Program students in the Evaluation of learning outcomes course. In the research on the effect of Hybrid learning with the PBL model, the independent variable is the application of Hybrid learning teaching materials with the PBL model and learning outcomes is the dependent variable. Therefore, the research was conducted with a quasi-experimental model. A quasi-experimental method has been tried to determine the extent of the influence of the independent variables on the dependent variable. An experimental class and a control class have been established to apply the quasi-experimental method. The quasi-experimental posttest group design can be seen in the Table. 1.

Table 1. Experimental design.

\begin{tabular}{clc}
\hline Class Group & \multicolumn{1}{c}{ Treatment } & Posttest \\
\hline A & Hybrid learning with PBL & Final Test \\
B & Traditional with direct instructional & Final Test \\
\hline
\end{tabular}

\section{Participants and Data Collection}

The research subjects in this study was students of the Unimed Business Education Study Program who attended the evaluation of learning outcomes course consisting of two classes (A and B) totaling 53 participants. The data collected results from the learning outcomes evaluation course of learning outcomes after students have attended lectures for eight meetings, originating from two classes (A and B). Class A was acted as experiment group, and class B as control group. In Class A, Hybrid learning was applied with problem-based learning, while Class B used conventional teaching materials with direct learning.

\section{RESULTS AND DISCUSSION}

Result

The collected data were analyzed using Mann-Whitney $U$ as a nonparametric test because the data distribution was not normal (Field, 2009; Siegel, 1956). A summary of 
The Effectiveness of the Hybrid Learning Materials with the Application of Problem Based Learning Model (Hybryd-PBL) to Improve Learning Outcomes during the COVID-19 Pandemic

the results of the study is shown in table 3, while student learning outcomes in the treatment and control classes can be seen in Table 2 .

Table 2. Descriptive statistics of learning outcomes.

\begin{tabular}{lcc}
\hline Statistic & $\begin{array}{c}\text { Hybrid Learning with PBL } \\
\text { (Experimental Group) }\end{array}$ & $\begin{array}{c}\text { Direct Instructional } \\
\text { (Control Group) }\end{array}$ \\
\hline Mean & 88.96 & 87.4 \\
Minimum & 85 & 85 \\
Maximum & 92 & 91 \\
\hline
\end{tabular}

Table 3 shows that the average learning outcomes in the Evaluation course of the experimental class students' learning outcomes were taught using hybrid learning with PBL was 88.96. The highest score was 92, and the lowest was 85 . Furthermore, control group which taught by Direct Instructional without using hybrid learning, the mean was 87.4. This is lower than the experimental class. The highest score in the control group was 91, and the lowest was 85 . The results of hypothesis testing on applying hybrid learning to learning outcomes in the evaluation of learning outcomes can be seen in Table 3.

Table 3. Mann-whitney U-test.

\begin{tabular}{lr}
\hline & Value \\
\hline Mann-Whitney U & 232.000 \\
Wilcoxon W & 610.000 \\
Z & -2.316 \\
Asymp. Sig. (2-tailed) & 0.021 \\
\hline
\end{tabular}

Based on the results of the Mann-Whitney $U$ test analysis, it is known that $\mathrm{U}=232, \mathrm{z}$ $=-2,316, p<.05$. This analysis shows a significant difference in the learning outcomes of students in the experimental group and control group.

\section{Discussion}

This study's findings, shows that the application of Hybrid learning teaching materials with the PBL model provides many opportunities to study concepts and case exercises related to the evaluation of learning outcomes. This study's results are supported by many previous studies (Greenhow \& Gleason, 2017; Kintu et al., 2017; O' Shea et al., 2015). All previous studies also concluded that Hybrid learning could be the best learning to improve learning outcomes. This quasi-experimental research is focused on the use of Hybrid learning teaching materials with the PBL model in teaching courses in the evaluation of student learning outcomes in the Business Education Study Program. The effectiveness of using Hybrid learning teaching materials with PBL is specifically designed to be applied to students for eight lectures through online learning (elearning) SIPDA Unimed. To analyze the level of effectiveness of using Hybrid learning teaching materials, a post-test was carried out. The findings of this quasi-experimental study indicate that the learning outcomes of the evaluation course of student learning outcomes who are taught using Hybrid learning with the PBL model are higher than students who are taught without teaching materials Hybrid learning with the direct instructional learning model. There was a significant difference in the average learning outcome test between the two groups at the end of the experiment. In this experiment, it has been identified that there is a significant difference in student learning outcomes 
between the experimental class and the control class. Because the average score is higher in the experimental group and significant at the $95 \%$ confidence level, data analysis shows that the use of Hybrid learning teaching materials with the PBL model is effectively used in the course of evaluating student learning outcomes of the Business Education Study Program. Therefore, Hybrid learning materials have a positive and significant effect in improving student learning outcomes in the Evaluation course of learning outcomes.

It is necessary to provide complete facilities and learning resources to support student learning success. Students will be able to access information anywhere, anytime without being limited by space limitations by applying Hybrid learning teaching materials with the PBL model. Hybrid learning teaching materials with the PBL model that encourage increased student learning outcomes. Through SIPDA Unimed elearning, discussions were held with lecturers and fellow students. Concepts that are difficult to understand can be overcome through discussion in discussion forums on elearning. This causes students to be able to solve the learning problems they face more quickly. Teaching materials are audio-video, handouts in the form of power points, specially prepared and uploaded to SIPDA e-learning for learning materials every week, and six main tasks, namely routine assignments and critical book reports, critical journal reports, mini-research and engineering. The student will immediately know the assessment of student exams and assignments after the lecturer gives an assessment. This study's main objective was to determine the impact of learning using hybrid learning teaching materials with the PBL model in the Unimed Business Education Study Program.

\section{CONCLUSIONS}

This study discusses the application of Hybrid learning teaching materials with the PBL (Hybrid-PBL) model in the Evaluation course of learning outcomes. Evaluation of learning outcomes is a course aimed at student-teacher candidates to compile a learning outcome test at a high level of thinking (HOTS) to analyze the validity, reliability of the level of difficulty, and the difference in the test. The best application (Hybrid-PBL) was during the Covid 19 pandemic and the era of the Industrial Revolution 4.0. The application of information technology through teaching materials (Hybrid-PBL) provides good interaction and communication compared to direct (conventional) learning. The benefits of learning with (Hybrid-PBL) prove that it can shape student teacher candidates to have qualified pedagogic competencies and character. The findings of this study reveal an understanding of the use of Hybrid learning teaching materials with the PBL model in learning the evaluation of learning outcomes, how well it can be used as an instructional design strategy at Medan State University in general and the Faculty of Economics, in particular, to support learning in improving pedagogic competence. Therefore, this study shows the importance of designing learning models and teaching materials that relate to curriculum content using information technology through learning management systems (LMS), which is SIPDA Unimed. This study is different compared to previous studies. Most of the previous researchers focused on developing teaching materials and then measured their feasibility without linking to a specific learning model. In this study, researchers have tested Hybrid learning teaching materials' effectiveness with the PBL (Hybrid-PBL) model in improving learning outcomes. Furthermore, it is scarce for researchers to find the same research in the context of learning. Evaluation of learning outcomes that can be used as a benchmark in 
learning. Evaluation of learning outcomes at universities that prepares students to become prospective teachers. This study provides empirical knowledge about the effectiveness of Hybrid learning with the PBL (Hybrid-PBL) model in teaching-learning outcomes evaluation courses, which will encourage educational institutions to adopt Hybrid teaching materials with the PBL (Hybrid-PBL) model in learning. However, this research is limited because this research only focuses on the evaluation course of learning outcomes. The gap-related to internet facilities is also a limitation in this study. Besides, further research on the pedagogic competencies of other subjects, such as the lesson planning course, learning strategies needs to be further investigated.

\section{ACKNOWLEDGEMENTS}

This research was funded by internal funds for Non-Tax State Revenue (PNBP), State University of Medan Number: 060 / UN33.8 / PL-PNBP / 2020. We also thank the Chancellor of Unimed and the Head of the Institute for Research and Community Service, who gave us the opportunity to conduct this research.

\section{REFERENCES}

Tuapattinaya, P. M. J. (2017). Pengembangan media pembelajaran biologi berbasis hybrid learning untuk meningatkan hasil belajar siswa pada smp negeri 6 Ambon. Biosel: Biology Science and Education, 6(2), 186-192.

Anderson, L. W., Bloom, B. S., \& others. (2001). A taxonomy for learning, teaching, and assessing: A revision of Bloom's taxonomy of educational objectives. New York: Longman.

Arends, R. I. (2012). Learning to teach (Ninth Edit). McGraw-Hill.

Berkson, L. (1993). Problem-based learning. Academic Medicine, 68(10), 79-88. https://doi.org/10.1097/00001888-199310000-00053

Bloom, B. S. (1956). Taxonomy of educational objectives, handbook the cognitive domain. New York

Bolliger, D. U. (2004). Key factors for determining student satisfaction in online courses. International Journal on E-Learning, 3(1), 61-67.

Calfee, R. (1996). Looking at technology in context: A framework for understanding technology and educational research. New York.

Cantillon, P., Wood, D. F., \& Yardley, S. (2017). ABC of learning and teaching in medicine. BMJIBooks

Carrió, M., Larramona, P., Baños, J. E., \& Pérez, J. (2011). The effectiveness of the hybrid problem-based learning approach in the teaching of biology: A comparison with lecturebased learning. Journal of Biological Education, 45(4), 229-235. https://doi.org/10.1080/00219266.2010.546011

Ceylan, V. K., \& Kesici, A. E. (2017). Effect of blended learning to academic achievement. Journal of Human Sciences, 14(1), 308-320.

Cindy, E., \& Hmelo-Silver. (2004). Problem-based learning: What and how do students learn? Educational Psychology Review, 16(3), 235-266.

Cognition, \& at Vanderbilt, T. G. (1990). Anchored instruction and its relationship to situated cognition. Educational Researcher, 19(6), 2-10.

Field, A. (2009). Discovering statistics using SPSS. Sage publications.

Greenhow, C. M., \& Gleason, B. W. (2017). Hybrid learning in higher education: The potential of teaching and learning with robot-mediated communication. ERIC, 21(4), 159-176.

Hariadi, B., Dewiyani Sunarto, M. J., \& Sudarmaningtyas, P. (2016). Development of web-based learning application for generation z. International Journal of Evaluation and Research in Education, 5(1), 60-68. https://doi.org/10.11591/ijere.v5i1.4523

Hartling, L., Spooner, C., Tjosvold, L., \& Oswald, A. (2010). Problem-based learning in preclinical medical education: 22 years of outcome research. Medical Teacher, 32(1), 28-35. 
The Effectiveness of the Hybrid Learning Materials with the Application of Problem Based Learning Model (Hybryd-PBL) to Improve Learning Outcomes during the COVID-19 Pandemic

https://doi.org/10.3109/01421590903200789

Hayashi, R., Garcia, M., \& Maddawin, A. (2020). Online learning in sri lanka's higher education institutions during the COVID-19 pandemic. Asian Development Bank.

Horn, M. B., \& Staker, H. (2011). The rise of K-12 blended learning. Innosight Institute, 5(1), 1-17.

Kintu, M. J., Zhu, C., \& Kagambe, E. (2017). Blended learning effectiveness: The relationship between student characteristics, design features and outcomes. International Journal of Educational Technology in Higher Education, 14(1), 1-20.

Krajcik, J., \& Czerniak, C. M. (2007). Teaching science to children: A project-based science approach. Mahwah NJ: Lawrence Erlbaum.

Krathwohl, D. R. (2002). A revision of bloom' s taxonomy: An otherview. Theory Into Practice, $41(4), 212-218$.

Lin, O. (2008). Student views of hybrid learning. Journal of Computing in Teacher Education, 25(2), 57-66. https:// doi.org/10.1080/10402454.2008.10784610

Martin, F., \& Bolliger, D. U. (2018). Engagement matters: Student perceptions on the importance of engagement strategies in the online learning environment. Online Learning Journal, 22(1), 205-222. https://doi.org/10.24059/olj.v22i1.1092

Michel, M. C., Bischoff, A., \& Jakobs, K. H. (2002). Comparison of problem and lecture-based pharmacology teaching. Trends in Pharmacological Sciences, 23(4), 168-170. https://doi.org/10.1016/S0165-6147(00)01940-4

O' Shea, S., Stone, C., \& Delahunty, J. (2015). “I 'feel' like I am at university even though I am online." Exploring how students narrate their engagement with higher education institutions in an online learning environment. Distance Education, 36(1), 41-58. https://doi.org/10.1080/01587919.2015.1019970

Olapiriyakul, K., \& Scher, J. M. (2006). A guide to establishing hybrid learning courses: Employing information technology to create a new learning experience, and a case study. Internet and Higher Education, 9(4), 287-301. https://doi.org/10.1016/j.iheduc.2006.08.001

Peters, A. S., Greenberger-Rosovsky, R., Crowder, C., Block, S. D., \& Moore, G. T. (2000). Longterm outcomes of the new pathway program at harvard medical school: A randomized controlled trial. Academic Medicine, 75(5), 470-479.

Prensky, M. (2001). <ADDED> digital natives, digital immigrants. On the Horizon, 9(5), 1-6. https:/ / doi.org/10.1108/10748120110424816

Rovai, A. P., \& Jordan, H. M. (2004). Blended learning and sense of community: A comparative analysis with traditional and fully online graduate courses. International Review of Research in Open and Distance Learning, 5(2), 1-13. https:/ / doi.org/10.19173/irrodl.v5i2.192

Safaruddin, S., Degeng, I., Setyosari, P., \& Murtadho, N. (2020). The Effect of PjBL with WBL Media and Cognitive Style on Studentsâ $€^{\mathrm{TM}}$ Understanding and Science-Integrated Concept Application. Jurnal Pendidikan IPA Indonesia, 9(3), 384-395. doi:https://doi.org/10.15294/jpii.v9i3.24628

Schmidt, H., Dauphinee, W. D., \& Patel, V. L. (1987). Comparing the effects of problem-based and conventional curricula in an international sample. Academic Medicine, 62(1), 305-315.

Siegel, S. (1956). Nonparametric statistics for the behavioral sciences. McGraw-Hill.

Singh, R., \& Adhikari, R. (2020). Age-structured impact of social distancing on the COVID-19 epidemic in India. ArXiv

Slavin, R. E., Madden, N. A., Dolan, L. J., Wasik, B. A., Ross, S. M., \& Smith, L. J. (1994). "Whenever and wherever we choose": The replication of 'success for all'. The Phi Delta Kappan, 75(8), 639-647.

Tan, O.-S. (2021). Problem-based learning innovation: Using problems to power learning in the 21st century. Gale Cengage Learning.

Tiwari, A., Lai, P., So, M., \& Yuen, K. (2006). A comparison of the effects of problem-based learning and lecturing on the development of students' critical thinking. Medical Education, 40(6), 547-554. https:// doi.org/10.1111/j.1365-2929.2006.02481.x

Vernon, D. T., \& Blake, R. L. (1993). Does problem-based learning work? A meta-analysis of 
The Effectiveness of the Hybrid Learning Materials with the Application of Problem Based Learning Model (Hybryd-PBL) to Improve Learning Outcomes during the COVID-19 Pandemic

evaluative research. Academic Medicine, 68(7), 550-563. https://doi.org/10.1097/00001888199307000-00015

Wijaya, P. A., \& Suyono, A. (2019). Profil kemampuan mahasiswa dalam mengembangkan instrumen tes mengacu standar hots pada mata kuliah evaluasi dan teknik pencapaian hasil belajar. PEKA, 7(2), 15-20.

\section{${ }^{*}$ Dr. Thamrin, M.Si. (Corresponding Author)}

Department of Business Education Faculty of Economics,

Universitas Negeri Medan,

Jl. William Iskandar Ps. V, Medan, North Sumatra, 20221, Indonesia

Email: thamrin@unimed.ac.id

\section{Dr. Saidun Hutasuhut, M.Si.}

Department of Management Faculty of Economics,

Universitas Negeri Medan,

Jl. William Iskandar Ps. V, Medan, North Sumatra, 20221, Indonesia

\section{Reza Aditia, M.Pd.}

Postgraduate School,

Universitas Negeri Medan,

Jl. William Iskandar Ps. V, Medan, North Sumatra, 20221, Indonesia

\section{Fauziyah Riyan Putri, S.Pd.}

Postgraduate School,

Universitas Negeri Yogyakarta,

Jl. Colombo Yogyakarta No.1, Yogjakarta, Special Region of Yogyakarta, 55281, Indonesia 